ISSN 1012-277X S.Afr.j.ind.eng. $-17-$

S A Journal of Industrial Engineering, Vol 8, No 1, June 1994, pp 17-37 1

Schmenner's Product-Process Matrix.

A Critque using S.A. Book Printers

Bukula M.S. and Snaddon D.R.

\begin{abstract}
This explores Schmenner's predictions of the product-process matrix using book printing firms in S.A. It measures focus in each book printing firm, and then examines relationships between measures. This study finds that these measures are not well behaved in the way Schmenner predicts and more research is needed on Schmenner's predictions.
\end{abstract}

\title{
PRODUCT-PROCESS MATRIX
}

Schmenner (1990, p.238\& 253) associates process changes with product changes on a product-process matrix (see Table 1). As process patterns change from job shops to continuous flow production there are changes in the product mix and challenges to management. The changes are:

a decline in the number of kinds of products made, an increase in product volumes,

a decline in product customisation and an increase in product standardisation, and

different challenges to management.

The matrix shows that as the process pattern changes, product mix changes. On the product mix axis the product variety reduces as volumes increase. Both Schmenner and Slack (1991, p. 129) show the shaded areas (off diagonal) as being high cost areas in the product-process matrix. Others point to parts of this association. For example Hill (1985, p.78)

${ }^{1}$ For any good in this DEO GLORIA. 
Table 1. THE PRODUCT-PROCESS MATRIX

\begin{tabular}{|c|c|c|c|c|c|}
\hline & \multicolumn{4}{|c|}{ Product Mix } & \multirow[b]{2}{*}{$\begin{array}{l}\text { Challenges to } \\
\text { Management }\end{array}$} \\
\hline Process Pattern & One of a kind & $\begin{array}{l}\text { Low } \\
\text { volumes; } \\
\text { many } \\
\text { products }\end{array}$ & $\begin{array}{l}\text { High vols.; } \\
\text { several } \\
\text { major } \\
\text { products }\end{array}$ & $\begin{array}{l}\text { Very high } \\
\text { volumes; } \\
\text { standard product }\end{array}$ & \\
\hline $\begin{array}{l}\text { Very jumbled flow; } \\
\text { process segments } \\
\text { loosely linked }\end{array}$ & $\begin{array}{l}\text { Project } \\
\text { Pure job shop }\end{array}$ & Job shop & & & \multirow{6}{*}{$\begin{array}{l}\text { Scheduling; } \\
\text { materials handling; } \\
\text { shifting bottlenecks } \\
\text { worker; motivation; } \\
\text { balance; maintaining } \\
\text { enough flexibility } \\
\text { Capital expenses for } \\
\text { big chunk capacity; } \\
\text { technological } \\
\text { change; materials } \\
\text { management; vertical } \\
\text { integration }\end{array}$} \\
\hline $\begin{array}{l}\text { Jumbled flow but a } \\
\text { dominant flow exists }\end{array}$ & & Batch flow & & & \\
\hline $\begin{array}{l}\text { Line flow } \\
\text {-Worker Paced }\end{array}$ & & Line flow & & & \\
\hline -Machine Paced & & & Line flow & & \\
\hline $\begin{array}{l}\text { Continuous, } \\
\text { automated, and rigid } \\
\text { flow; process } \\
\text { segments tightly } \\
\text { linked }\end{array}$ & & & & Continuous flow & \\
\hline $\begin{array}{l}\text { Challenges to } \\
\text { Management }\end{array}$ & $\begin{array}{l}\text { Bidding; } \\
\text { delivery; } \\
\text { product design; } \\
\text { flexibility }\end{array}$ & \multicolumn{2}{|c|}{$\begin{array}{l}\text { Quality (product } \\
\text { differentiation); } \\
\text { flexibility in output } \\
\text { volumes }\end{array}$} & Price & \\
\hline
\end{tabular}


declares that: "Companies choosing continuous process will be selling a narrow range of standard products."

Schmenner assumes competition, as non competitive organisations need not restrict costs by following the diagonal of the product-process matrix.

Schmenner lists major challenges to management in the last row

Table 2. RANKING OF CHALLENGES TO MANAGEMENT

\begin{tabular}{|c|c|c|c|}
\hline & \multicolumn{3}{|c|}{ Ranking } \\
\hline Manufacturer & First & Second & Third \\
\hline Project & Speed & Quality & Cost/Price \\
\hline $\begin{array}{l}\text { Batch \& Line } \\
\text { Flow }\end{array}$ & Quality & $\begin{array}{l}\text { Cost/Price \& } \\
\text { Speed }\end{array}$ & \\
\hline $\begin{array}{l}\text { Continuous } \\
\text { Flow }\end{array}$ & Cost/Price & Quality & Speed \\
\hline
\end{tabular}

of table 1 . Some of the challenges to management are similar to those distinctive characteristics by other authors (e.g. Slack, 1991) and we combine them. Project manufacturers regard product design and delivery (speed) as important. Batch and line flow manufacturers regard quality as important. Continuous producers rate price (cost) as most important. Using Schmenner's (1990, p. 253) challenges we expect the rankings given in table 2 .

\section{COMPETITION}

To compete the firm serves a particular segment well. Management develops each of the organisation's functional policies with this focus in mind by better meeting the needs of the particular segment, by lower costs or by some other characteristic perceived by the customers in this segment as distinct. In doing this, porter says that: "The firm achieving focus may also potentially earn above-average returns for its industry" (1980, p.39).

Best describes some of the distinctive characteristics that 
firms deliver, enabling them to compete well. He says: "Firms may compete, for example, on the basis of price, product quality, technological process, or product innovation." (1990, p. 166) Miller (1981, pp. 149-151) adds that people within the firm must agree on the priorities of these distinctive characteristics.

Focus must occur within the firm. Manufacturing activities must be aligned to perform the service demanded by the overall strategy and marketing aim of the company. (Miller, 1983, pp. 71-73; Stobaugh and Telesio, 1983). Manufacture that is aligned becomes a "focused factory", and skinner (1974) points out that a focused factory can become a competitive weapon.

Focus enhances productivity as: "increasing repetition of a task will lead to greater efficiency not only in terms of the time required to complete the task but also in the achievement of quality standards, that is greater standards of accuracy, etc." (Wild, 1990, p170). Wild (1990, p.32) recognises a clear focus or concentration of efforts, as a prerequisite for business success. By narrowing the range of demands placed on a manufacturing facility, Hayes and wheelwright (1984) assert that: "focusing manufacturing operations can have significant benefits; indeed it may be one of the most important factors affecting the overall performance of a production facility." (p.114). Miller agrees when he (1983, p.73) says: "experience confirms Wickham Skinner's argument that 'a focused factory' is the inescapable foundation for productivity." Focus leads to increases in profitability, competitiveness and productivity.

with the need to focus established, we review focused manufacturing then describe aspects of book printing. We then describe our research method and finally we present data, results and conclusions of the study.

\section{FOCUSED MANUFACTURING}

This looks at focused manufacturing to:- 
show that choices are necessary to focus, understand focus in two broad ways, establish the level at which people address focused manufacturing, recognise focus.

\section{The nature of manufacturing}

Hill (1985, p.99) says that manufacturing is "inherently a complex task. "By focusing manufacturing operations, employees avoid confusion and this is a reason for focus. A second reason is so that senior managers may manipulate manufacturing in particular, and the firm in general, to compete. With complex tasks and different ways to compete, authors tell how senior managers may focus their manufacturing operations. (Skinner, 1974; Chase and Hayes, 1981, p. 22-24; Miller, 1981; Hill, 1985, ch.4; Schmenner, 1990) A prerequisite of focusing manufacturing is then choice in manufacturing.

\section{Understanding focus.}

The goal of focus is to have the whole operation pulling in the same direction, as implied by the proclaimed corporate strategy (Schmenner, 1981, p. 386). Hayes and Wheelright (1984, p. 325) agree, saying that when there is confusion over priorities in an organisation, people expect employees to work at cross-purposes inconsistent with the real needs of the business. Explaining the essence of focused manufacturing, Skinner (1974, p.114) says:

"A factory that focuses on a narrow product mix for a particular market niche will outperform the conventional plant which attempts a broader mission. Because its equipment, supporting systems, and procedures can concentrate on a limited task for one set of customers, its costs and especially its overheads are likely to be lower than those of the conventional plant."

In this skinner offers two aspects of focus: 
(i) Focus on a narrow set of products for a particular market niche.

(ii) Focus on a limited manufacturing task instead of many inconsistent, conflicting tasks.

Hayes and Schmenner (1978, pp.110-114) call these two types of focus, product focus and process focus respectively.

Product focused organisations decentralise authority. Each product group is a small entity that can respond quickly to product development considerations. Lloyd (Anon, 1992, p91) advocates focus by creating separate businesses and profit centres, putting emphasis on the quality of the management and product, forcing management to do better. As time passes, Schmenner (1983, p.127) says that plants are more likely to make a broader range of products and have less stability in the mix of products they do make. To remain focused, people should devote attention to making few products on an ongoing basis.

A process focused organisation, according to Hill (1985, pp.100-101), emphasizes a limited and consistent set of tasks. The basis of focused manufacturing is homogeneous tasks with repetition of, leading to experience in, completing these tasks. Hayes and wheelright (1979, p.139) support this view pointing how it differs from the product argument. They say that while firms require a narrow focus for success in a single product market, large companies can and do effectively make multiple products to serve multiple markets. For example parts makers produce for original equipment and spares markets.

With two definitions of focus the question arises whether product and process focus are related or not. [Endnote 1]

A focused operation in a competitive market is at a point on the product-process matrix "diagonal". We use Skinner's first definition in assessing focus, noting that product range and volume are important characteristics of focus. 
The level at which focused manufacturing is addressed.

Hayes and Wheelright (1984, pp.110-114) give a four-level approach to assessing focus. Researchers can:

(i) compare several firms in a single industry.

(ii) compare several factories operated by the same company. (iii) measure focus in a single firm operating a single factory over time.

(iv) examine focus on the individual production line within a factory. (Researchers can measure focus by the number of product sizes produced on the particular line).

We assess focus by comparing several firms in a single industry.

\section{Recognizing focused manufacturing.}

According to Skinner (1974, pp.114-115) a focussed manufacturer recognises that there are many ways to compete in the marketplace. As a factory cannot perform well in every way, people make necessary trade-offs to perform a limited task well. The workforce and managers repeat the limited critical task and become effective and experienced. Focused manufacturers (Skinner, 1974, pp.115-116) limit unproven and uncertain technologies, only do well on one or two market demands, separate products by length of product run and/or variety, employing a common attitude and approach. They focus on a set of internally consistent, achieveable, noncompromised success criteria to perform tasks well to be competitive.

The product-process matrix describes manufacturers in competitive environments. To survive in a competitive environment, and providing there is choice to manoeuvre, the choice of a prticular product focus constrains the process focus and vice versa. The manufacturing unit chosen in this study is the łirm. We can examine "product" focus in terms of product range, volume and sizes, and challenges to management 
of book printing firms to find focus. (Schmenner, 1990, p. 238)

\section{BOOR PRINTING}

We define South African book printing and explain the various technologies available. Then we compare the S.A. industry with other countries. The clients that book printers supply is the particular segment whose wishes are crucial. We analyse these in terms of challenges to management to predict focus in S.A. book printing. From the product-process matrix and knowledge of S.A. book printing we finally measures of focus for research. This is used to check the theory presented.

\section{Definition of the book printing industry}

The dictionary defines a book as a literary portable printed number of sheets fastened together. (We specify that the sheets are made of paper). Printers impress or stamp inked types, blocks or plates to the sheets of paper. Books exclude single sheets (e.g. advertising bills) and items regularly produced say at maximum once a quarter (e.g. magazines and newspapers). We also exclude processes such as xerography. We restrict the use of the term book printing to that described above. Book printing calls for limited batches and some authors classify it as a job shop (Hayes and wheelwright, 1979, p. 128).

People often include book printing with other similar processes. For example the department of trade and industry combines book printing with "newspapers, pictures and other products of the printing industry; manuscripts, typescripts and plans." (Department of Trade and Industry, 1988, p.10, code 4900$)$. We provide information on general printing where evidence of book printing is not available. 


\section{Key characteristics}

Now we describe the technological choice facing book printers who want to focus. We separate the technology of book printing into printing and bookbinding. The technologies of book printing in table 3 show the general flow on the left hand side. Alternative processes are shown on the right hand side. Pre-press printers can choose to set-type or image. Pre-press costs are expensive as printers generally cannot re-use such work.

Printers require pre-press work for different texts, colours and sizes.

The printing industry can use four printing processes (Cahill, 1991, p.43)

(i) Printers traditionally use letterpress but now change to new printing processes.

(ii) Lithographic (offset) printing is most commonly used by commercial printers. Lithographic printing includes single and multi-colour production and uses sheet or web-fed printing.

(iii) Printers combine letterpress and lithographic printing into flexographic printing. They usually use flexographic printing for specialised products.

(iv) Printers mainly use gravure printing for long production runs. They use it in to produce magazines where speed of production and high quality are important. Gravure is suitable for printing large numbers of single titles.

Bookbinding is the process of putting pages between covers. While book printers bind some books by hand they bind the majority of books by machine. Printers fold the printed paper into a section that is called a signature. (Printers usually print between 2 and 32 pages on a single sheet).

They paste (called tipping in) or insert separate pages, depending upon the sewing technique used on the signature. They place signatures into bins to be collated into uncovered books which are then sewed or fastened with adhesives. There 
are different techniques of sewing called thread, side and saddle stitching although saddle stitching is rarely used. (Printers call fastening the signatures with various adhesives "perfect binding"). Trimming follows sewing. Covering is usually a choice between hard and soft covers but leather and cloth form other alternatives.

Table 3. TECHNOLOGIES OF BOOK PRINTING
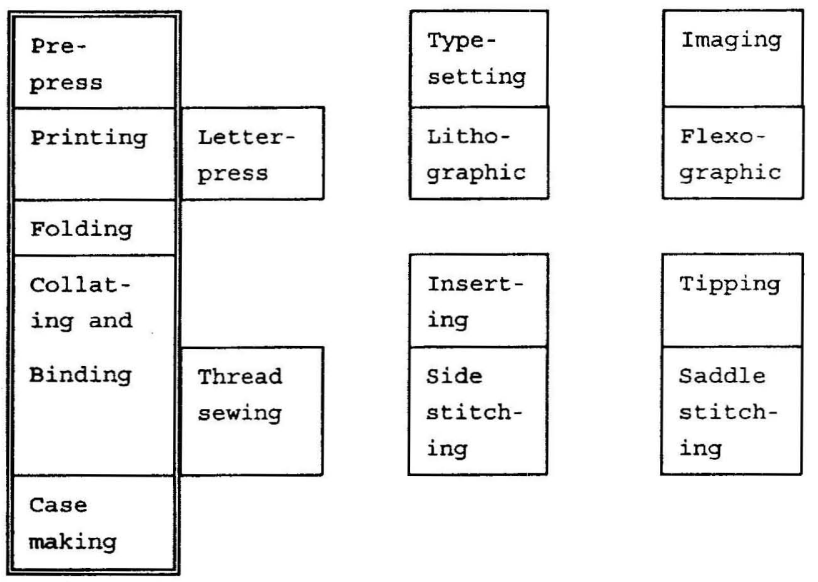

Gravure

\begin{tabular}{|l|}
\hline $\begin{array}{l}\text { Insert- } \\
\text { ing }\end{array}$ \\
\hline Side \\
stitch- \\
ing \\
\hline
\end{tabular}

\begin{tabular}{|l|}
\hline Tipping \\
\hline Saddle \\
stitch- \\
ing \\
\hline
\end{tabular}

\begin{tabular}{|l|}
\hline Perfect \\
binding
\end{tabular}

Taylor (1977, pp. 381-383) outlines recent technological changes in book printing. Up to the 1950 s printers bound most books in separate stages. In the 1950 s production line technologies started appearing and by the 1970s machines were developed that could print and bind books in a single operation with volumes over 6000 per hour.

In addition printers produce books in various sizes. There are over twenty two standard paper sizes. (Cahill, 1991, p.75) Printing techniques differ as do sewing and covering techniques. There is a large choice of technologies in book printing. Printers wishing to focus a book printing establishment must make many technological and other decisions. 
Table 4. INTERNATIONAL COMPARISONS OF PRINTING INDUSTRIES (1984-1985)

\begin{tabular}{|c|c|c|c|}
\hline Dimension & Hong Kong & Singapore & S.A. \\
\hline Establishments & 3102 & 326 & $985(\mathrm{p} .18)$ \\
\hline Number of Employees & 29554 & 14213 & 36347 (p.18) \\
\hline $\begin{array}{l}\text { Employees per } \\
\text { establishment }\end{array}$ & 9.5 & 43.6 & 36.9 \\
\hline \multicolumn{4}{|c|}{ Size distribution of employees in per cent } \\
\hline 0-19 Employees & 91 & 72 & 67 \\
\hline 20-99 Employees & 7 & 22 & 26 \\
\hline$>100$ Employees & 0.5 & 6 & $\begin{array}{l}7 \\
(p .66) !\end{array}$ \\
\hline Industry output & n.a. & $\begin{array}{l}\$ S 937.7 \mathrm{~m} \\
=\mathrm{R} 613.2 \mathrm{~m}\end{array}$ & $\begin{array}{l}\mathrm{R} 2030.4 \mathrm{~m} . \\
(\mathrm{p} .66)\end{array}$ \\
\hline Industry Exports & $\begin{array}{l}\text { \$HK1399*12/10 } \\
\mathrm{m} . \quad(\mathrm{p} .2-' 85) \\
=\mathrm{R} 8055 \mathrm{~m} .\end{array}$ & $\begin{array}{l}\$ S 82.1 / 0.68 \\
\text { m. }(p .4) \\
=R 78.9 \mathrm{~m} .\end{array}$ & R8.3m (1985) \\
\hline $\begin{array}{l}\text { Exports per employee } \\
\text { in ROOO's }\end{array}$ & 273 & 5.6 & 0.2 \\
\hline $\begin{array}{l}\text { Output per employee in } \\
\text { R000's }\end{array}$ & n.a. & 43 & 56 \\
\hline
\end{tabular}

\section{S.A. Book Printing}

S.A. book printing is classified within the printing and publishing subgroup which is within the printing, publishing and allied industries group. In 1985 this group made up some 7\% of establishments, employing $3,3 \%$ of employment producing some $3,8 \%$ of net output of manufacturing. (CSS, 1985, p. 4). The S.A. book printing industry is small. We compare the size 
and structure of printing in S.A. with two world class countries in book printing, namely Hong Kong and singapore. The comparisons are in table 4. The S.A. industry appears to employ more people than other countries listed in table 4. The comparative sizes of firms in South Africa and Singapore bear a close resemblance. However, S.A. imports more books than it exports. Its export performance is weak.

A printing industry at full capacity may have little scope to export. The performance of the printing industry relative to its capacity can be measured over time using the physical volumes produced (table 5) and reports on the utilisation of production capacity (table 6).

Table 5. S.A. PRINTING AND PUBLISHING- PHYSICAL VOLUMES

$(1985=100)$

\begin{tabular}{||l|l||l|l|l|l||}
\hline Year & Volume & Year & Volume & Year & Volume \\
\hline \hline 1990 & 94.8 & 1986 & 94.6 & 1982 & 94.9 \\
\hline 1989 & 95.7 & 1985 & 100.0 & 1981 & 90.0 \\
\hline 1988 & 96.2 & 1984 & 108.9 & 1980 & 86.1 \\
\hline 1987 & 93.7 & 1983 & 97.9 & 1979 & 76.0 \\
\hline
\end{tabular}

Source: CSS, 1992, p. 12.

Table 5 shows peak production in 1984 at 108.9 with recent volumes at about 95. Using tables 5 and 6 there has been a capacity contraction between 1984 and 1990. [Endnote 2] From tabl_ 6 the reason for under-utilisation is mainly insufficient demand. To improve utilisation and curtail contraction in the industry, printers need to pay close attention to client's wishes if printers want to survive. 
Table 6. UTILISATION OF PRODUCTION CAPACITY

IN S.A. PRINTING AND PUBLISHING

\begin{tabular}{||l|l|l|l|l|l|l|}
\hline Year & $\begin{array}{l}\text { Util- } \\
\text { isa- } \\
\text { tion }\end{array}$ & $\begin{array}{l}\text { Under- } \\
\text { utilisa } \\
\text {-tion }\end{array}$ & $\begin{array}{l}\text { Raw Materials } \\
\text { Labour Skilled } \\
\text { \& Unskilled }\end{array}$ & Other & $\begin{array}{l}\text { Insuffic } \\
\text {-ient } \\
\text { Demand }\end{array}$ & Source \\
\hline 1992 & 85.0 & 15.0 & 2.3 & 2.7 & 10.0 & $\begin{array}{l}\text { Feb } \\
\text { 93, } \\
\text { p.7 }\end{array}$ \\
\hline 1991 & 85.8 & 14.2 & 1.5 & 1.2 & 11.5 & $\begin{array}{l}\text { May } \\
\text { 92, } \\
\text { p.7 }\end{array}$ \\
\hline 1990 & 82.8 & 17.2 & 2.7 & 1.3 & 13.2 & $\begin{array}{l}\text { May } \\
\text { a2, } \\
\text { p.7 }\end{array}$ \\
\hline 1989 & 86.0 & 14.0 & 4.2 & $\begin{array}{l}\text { Feb. } \\
\text { (90, } \\
\text { p.6 }\end{array}$ \\
\hline 1984 & 89.2 & 10.8 & 1.6 & 2.2 & 7.6 & $\begin{array}{l}\text { Feb. } \\
\text { 90, } \\
\text { p.6 }\end{array}$ \\
\hline
\end{tabular}

Source: CSS, Various dates (see source' column).

\section{Competitiveness of the SA printing industry}

The National Productivity Institute studies client ratings of the most important criteria for S.A. book printers. Clients rate seventeen criteria from relatively unimportant (1) to very important (10). They rated the criteria for an ideal book printer and actual book printers. The most important criteria as well as the average for all seventeen criteria is in Table 7 .

The table shows important challenges to management in the domain of quality and delivery speed. Clients rate challenges 
such as product design (measured by creative artwork and layout) and pricing below quality and speed.

Table 7. CLIENTS' RATINGS OF. PRINTERS

\begin{tabular}{||l|l|l|l|}
\hline & $\begin{array}{l}\text { Ideal } \\
\text { Printer }\end{array}$ & $\begin{array}{l}\text { Average } \\
\text { Score }\end{array}$ & Difference \\
\hline $\begin{array}{l}\text { Accurate proofs delivered } \\
\text { promptly }\end{array}$ & 9.5 & 7.4 & 2.1 \\
\hline Meeting deadlines & 9.5 & 8.0 & 1.5 \\
\hline Quality of finished product & 9.5 & 8.1 & 1.4 \\
\hline Collation accuracy & 9.5 & 8.2 & 1.3 \\
\hline $\begin{array}{l}\text { Corrections to proofs made } \\
\text { promptly }\end{array}$ & 9.4 & 8.1 & 1.3 \\
\hline General co-operation & 9.4 & 8.5 & 0.9 \\
\hline Competitive pricing & 9.2 & 8.0 & 1.2 \\
\hline Quality of colour work & 9.1 & 8.3 & 0.8 \\
\hline Average of criteria above & 9.4 & 8.1 & 1.3 \\
\hline Average of all criteria & 8.2 & 7.3 & 0.9 \\
\hline
\end{tabular}

Source: National Productivity Institute, 1987, p.59.

The table also shows discrepancies between what clients want and what book printers deliver. Differences between what clients want and what book printers deliver are more pronounced for the most important challenges to management. (The criterion with the greatest difference is delivering accurate proofs promptly. This criterion combines quality and speed).

If we place the management challenges of quality and speed on the product-process matrix (table 1) then we see that clients want management to focus in the "low volumes-many products" to "high volumes-several major products" business. Alternatively, they should use batch or line flow. There may be a contradiction between Hayes and wheelwright 
(1979, p.128) classification of commercial printers as a typical job shop, and the evidence gained on the book printing industry. The evidence, using Schmenner's product-process matrix (table 1) points to S.A. book printing as ranging between a job shop and a line flow operation.

\section{Assessing focus in book printing}

We measure focus in terms of product mix and challenges to management found on the product-process matrix and with the knowledge of book printing technologies. Specifically we use for product mix

(i) the range of products manufactured,

(ii) the lengths of product runs (volumes), and

(iii) the sizes and colours of products.

For challenges to management we use

(iv) price, quality, speed and other (e.g. flexibility, bidding etc.)

We assess focus in the book printing industry with these measures.

\section{RESEARCH METHOD}

We find focus of S.A. book printers by answering the following questions:

(i) What is the range of books that the firm prints? We use the products: textbooks, diaries, and Bibles.

(ii) What volumes are printed in these ranges?

(iii) Are products standard or customised regarding size and colour?

(iv) Is the firm focused on price, quality, speed or something else?

second, we test the relationships postulated by Schmenner on the product-process matrix in Table 1 .

The sample frame is all competitive book printing firms in the country. We exclude printing departments, the Government 
printer and anything else which may be a monopoly. There are about 1000 establishments in printing and publishing. Most establishments are small (CSS, 1985, p. 108) are not book printing establishments.

We use the Printing Industries Federation of South Africa (PIFSA) membership of seventeen book printers. In the expert opinion of $\mathrm{Mr}$. E. KÜhl Director of AIP(SA) this includes vitually all competitive book printers in South Africa.

We got the sample data from these printers using a combination of a questionnaire and telephone interviews.

During pilot research we simplified the questionnaire to make it possible for respondents to understand the questions and to avoid technical terms.

We use multiple-choice questions to make sure of the uniformity of responses and to ease analysis. Most questions allow for respondents' addition to the list of possible answers provided in the questionnaire. This makes sure that we include issues considered by respondents to be important.

[Endnote 3]

We identified a person in each firm anci, once the person gave permission, we sent the questionnaire with a covering letter. The letter guaranteed confidential ty of information, anonymity of the respondent, and thanked the respondent for their help.

\section{DATA ANALYSIS, RESULTS, AND CONCLUSIONS}

Of seventeen questionnaires sent, we have sixteen completed responses. We analyse the data and constructed frequency tables for each of the measure - product range, volumes, sizes, and competitive variables. Finally, we córrelate data for four measures of focus to check the relationships postulated by Schmenner (see table 1) between measures. We give the results and conclusion for the product range, volumes, sizes, price and the challenges to management in tables $8-11$. 
Table 8. PRODUCT RANGE

\begin{tabular}{|l|l|l|l|l|}
\hline $\begin{array}{l}\text { Printers of Textbooks Alone, Textbooks \& Diaries, Textbooks \& Bibles } \\
\text { [Endnote 4] and All three categories }\end{array}$ \\
\hline Textbooks & Alone & + Diaries & + Bibles & All \\
\hline Number & 8 & 5 & 1 & 2 \\
\hline
\end{tabular}

Most respondents printed textbooks alone, followed by textbooks and diaries. Over two thirds of the respondents have average product volumes of less than 10 000. This compares with large book printers in Hong Kong who resist orders under 10 000. (Tory, 1987, p. 4) Most respondents printed up to three different product sizes. The minimum number of sizes printed is two and only one respondent prints four sizes. This compares to more than twenty-two standard paper sizes for the standard A, B and C series. (Cahill, 1991, p. 75)

Table 9 .

PRODUCT VOLS.

\begin{tabular}{|l|l|l|}
\hline OoOs & $\begin{array}{l}\text { No. of } \\
\text { Obs. }\end{array}$ & z \\
\hline $0-5$ & 3 & 19 \\
\hline $5-10$ & 8 & 50 \\
\hline $10-15$ & 3 & 19 \\
\hline $15-$ & 2 & 12 \\
\hline Total & 16 & 100 \\
\hline
\end{tabular}

Table 10. PRODUCT SIZES

\begin{tabular}{||l|l|l|}
\hline $\begin{array}{l}\text { No. of } \\
\text { Sizes }\end{array}$ & $\begin{array}{l}\text { No. } \\
\text { of } \\
\text { Obs. }\end{array}$ & \% \\
\hline 1 & 0 & 0 \\
\hline 2 & 5 & 31 \\
\hline 3 & 10 & 63 \\
\hline 4 & 1 & 6 \\
\hline Total & 16 & 100 \\
\hline
\end{tabular}

From table 11 managers of book printers see their challenges in the following order: quality, price, speed then other.

We correlate range, volume, size and price. This exercise establishes relationships existing between measures of focus postulated by Schmenner (see table 2). We calculate the measure of determination, "r-squared." Table 12 shows the results of this analysis. 
Table 11. CHALLENGES TO MANAGEMENT

\begin{tabular}{|l|l|l|l|l|}
\hline Variable & Quality & Price & Speed & Other \\
\hline $\begin{array}{l}\text { Most } \\
\text { Important }\end{array}$ & 13 & 11 & 8 & 3 \\
\hline Important & 2 & 5 & 7 & 3 \\
\hline $\begin{array}{l}\text { Not Very } \\
\text { Important }\end{array}$ & 1 & 0 & 1 & 1 \\
\hline Blank & 0 & 0 & 0 & 9 \\
\hline Total & 16 & 16 & 16 & 16 \\
\hline
\end{tabular}

Table 12. CORRELATION BETWEEN THE MEASURES OF FOCUS

\begin{tabular}{|l|l|l|l|}
\hline & Volume & Size & Price \\
\hline Product Range & 0.38 & 0.06 & 0.13 \\
\hline Volume & & 0.07 & 0.08 \\
\hline Size & & & 0.03 \\
\hline
\end{tabular}

(Correlation measured by $R^{2}$ with 14 degrees of freedom)

We find no strong association between variables. The strongest association is between product range and volumes. This positive correlation means that, as product range increases, so does volume.

\section{Conclusions}

In this study respondents tend to print more products than books. This contrast with the focus of Hong Kong and singapore book printers. "Hong Kong and Singapore... (c)ompanies .. produce books and barely anything else. Thus they are specialists and 'experts'." (Tory, 1987, p.ii). This dilutes focus revealed by the data in this study. Our finding is that, within books, respondent firms focus weakly by printing a limited range and size of books. International competitiveness 
as measured by export performance is weak, especially when the particular needs of the Southern African region are recognised. We do not apportion any blame from our findings as other factors such as trade policies have not been researched. (see for example Belli et al, 1993)

production volumes and sizes point to batching operations. The challenges to management results in the following ranking. Quality ranks first, then price (cost in the market) and lastly speed. From the analysis in table 2 we see that the rankings suggest larger batch sizes as price (cost in the table) is more important than speed. Competitive book printers tend into line type flow shown on the product-process matrix. This mirrors developments in technology from the 1950's onwards.

There is weak correlation between measures given on the product-process matrix. This may show independence of measures where Schmenner expects definite associations. A confusing result is a positive correlation between product range and volume. According to the product-process matrix (see table 1), this relationship should be negative. That is, as product range decreases, volumes increase. This study, however, shows that volumes increase as product range increases and vice versa. The following factors might explain this.

(i) The study did not investigate whether the respondents' operations were involved in printing products besides books and this biases the results.

(ii) Some of Schmenner's measures are not adequately proxied by the measures of focus we used.

(iii) That Schmenner's challenges to management (see table 1) are not correct. Ferdows and de Meyer (1990) have recently challenged the contingent nature of Schmenner's theory.

It would be interesting to find out which of these explanations holds true in this case. This question is, however, a topic for further research. 


\section{ENDNOTES}

1. Other taxonomies of focus exist (e.g. Hayes and wheelright, 1984; p. 90 and slack 1991, p. 115) but the product-process focus is the subject of our research.

2. If 1984 was at 89.2 per cent of capacity (see table 5) this places 1990 utilisation at $(.892 \star 94.8 / 108.9)$ about 78 per cent of 1984 capacity. Table 6 indicates a utilisation of 82.8 percent indicating a contraction in capacity in the intervening years.

3. Major limitations of this method are:

(i) Multiple-choice questions limit the respondent to predetermined answers.

(ii) Simplification of terms may compromise their meaning.

4. Bibles are an example of books where pre-press work may be reused.

\section{REFERENCES}

Anon, (1992). "A Slippery slope to Perdition?". Einancial Mail, 25 september, p.91.

Belli, P., Finger M. and Ballivian A., (1993). South Africa-A Review of Trade policies. Washington: World Bank Southern Africa Department. Discussion Paper No. 4, August.

Best, M.H., (1990). The New Competition: Institutions of Industrial Restructuring. Cambridge: Polity Press, 296 pages.

Cahill, J. (ed.), (1991). "1991 IBIS Business Information Report on the Printing and Bookbinding Business Sector". Australian Printing Industry Yearbook 1991. Sydney: Printing and Kindred Industries Union, pp.39-49.

Chase, R.B. and Hayes, R.H., (1991). "Beefing Up Operations in Service Firms". Sloan Management Review, Fall. pp.15-26.

CSs, (1985) Central Statistical Services, Census of Manufacturing, 1985. Report No. 30-01-01. Pretoria: Government Printer, 284 pages.

CSS, (1992) Central Statistical Services, Manufacturing statistics Indicies of Physical Volume of Manufacturing Production Base 1985=100, Jan. 1978- Nov. 1991, 9 March 1992, No. P 3041.3, Pretoria: Government Printer.

CSS, (Various dates). Central statistical services, Utilisation of Production Capacity, Statistical Newsletter P3043, various dates, Pretoria: Government Printer.

Department of Trade and Industry (1991) and the IDC. Make it in the RSASelected Trade Statistics (1991). Pretoria.

Department of Trade and Industry (1988) and the IDC. Make it in the RSA1988 Import statistics. Pretoria.

Ferdows, K. and De Meyer, A. (1990) Lasting Improvement in Manufacturing Performance. In Search of a New Theory, Journal of operations Management, Vol. 9, No. 2, April, pp. 168-184.

Hayes, R.H. and Schmennex, R.W., (1978). "How Should You Organise Manufacturing". Harvard Business Review. January-February, pp.105-118.

Hayes, R.H. and Wheelright, S.C., (1979). "Link Manufacturing Process and Product Life Cycle". Harvard Business Review. January-February, pp.133140 .

Hayes, R.H. and Wheelright, S.C., (1984). Restoring our Competitive Edge: Competing Through Manufacturing. New York: John Wiley and Sons, 427 pages . 
Hill, T., (1985). Manufacturing strategy: The Strategic Management of the Manufacturing Function. London: Macmillan, 230 pages.

Kinnear, T.C. and Taylor, J.R., (1979). Marketing Research: An Applied Approach. New York: McGraw-Hill, 656 pages.

Miller, J.C., (1981). "Fit Production Systems to the Task". Harvard Business Review. January-February, pp.145-154.

Miller, S.S., (1983). "Make Your Plant Manager's Job Manageable". Harvard Business Review. January-February, pp.68-74.

National Productivity Institute (1987), Productivity study of Book and Commercial printing in South Africa, Pretoria: National Productivity Institute, $141 \mathrm{pp}$.

Porter, M.E., (1980). Competitive Strateqy: Techniques for Analysing Industries and Competitors, New York: Free Press,

396 pages.

Schmenner, R.W., (1981). Production/Operations Manaqement: Concepts and Situations. Chicago: Science Research Associates, 422 pages.

Schmenner, R.W., (1983). "Every Factory Has a Life Cycle". Harvard Business Review. March-April, pp.121-129.

Schmenner, R.W., (1990). Production/operations Management: Concepts and Situations. $4 \mathrm{th}$ ed. New York: Macmillan, 797 pages.

Skinner, W., (1974). "The Focused Factory". Harvard Business Review. MayJune, pp.113-121.

Skinner, W., (1969). "Manufacturing - Missing Link in Corporate Strategy". Harvard Business Review. May-June, pp.136-145.

Slack, N.D.C., (1991). The Manufacturing Advantage London: Mercury, 214 pages.

Stobaugh R. and Telesio P., (1983). "Match Manufacturing Policies and Product Strategy". Harvard Business Review. March-April, pp.113-120.

Taylor, T.E. (1977). "Bookbinding" In: The World Book Encyclopedia. Field Enterprises Educational Corporation, ISBN 0-7166-0077-3.

Tory, B., (1987). "Competitiveness of the Australian Printing Industry: Book and Magazine Printing, Pre-Press". Report to Paper Conversion, Printing and Publishing Industry Council. New South wales.

Trade Statistics, (1985). "R.S.A. Monthly Abstract of Trade StatisticsJan.-Dec. 1985" Pretoria: Government Printer.

wild, R., (1990). Essentials of Production and operations Manaqement. 3xd ed. London: Cassell Educational, 420 pages. 